\title{
Assessment of acceptable tourism beach carrying capacity in both normal and COVID-19 pandemic conditions - case study of the Town of Mali Lošinj
}

\section{Procjena prihvatljivog turističckog prihvatnog kapaciteta plaža u normalnim uvjetima i u uvjetima pandemije COVID-19 - studija slučaja Grada Malog Lošinja}

The paper presents an assessment of the acceptable tourist bathing load with regard to the physical, real, and effective carrying capacity of coastal beaches. In the case study of the Town of Mali Lošinj (Croatia), the paper scrutinises the carrying capacity of beaches categorised according to their basic characteristics and presents an analysis of beach capacity in the real conditions of the 2018 tourist season and in three hypothetical scenarios, two of which involve the application of recommendations for COVID-19 epidemiological measures. The basic hypothesis of the paper is that the real carrying capacity of beaches in the researched area under normal conditions is close to the upper load limits and that the carrying capacity of beaches will no longer be sufficient (vis-à-vis demand) when epidemiological recommendations are applied. The aim of this paper is to provide measurable bases for sustainable physical plans and development policies in tourism.

Key words: tourism, beach, beach carrying capacity, COVID-19 pandemic, Mali Lošinj
Rad prikazuje procjenu prihvatljive turističke kupališne opterećenosti s obzirom na fizički, realni i efektivni prihvatni kapacitet morskih plaža. Na primjeru studije slučaja Grada Malog Lošinja (Hrvatska) rad razmatra prihvatni kapacitet plaža kategoriziranih prema svojim osnovnim obilježjima te prikazuje analizu opterećenosti plaža u realnim uvjetima turističke sezone 2018. i u tri hipotetska scenarija od kojih dva uključuju primjenu protuepidemijske mjera COVID-19. Osnovna hipoteza rada glasi kako je realni prihvatni kapacitet plaža na istraživanom prostoru u uvjetima uobičajene turističke kupališne sezone blizu gornjih granica opterećenosti te da prihvatni kapacitet plaža nije dovoljan pri sadašnjem broju korisnika ako se primjenjuju protuepidemijske preporuke. Cilj je rada pružiti mjerljive osnove za oblikovanje održivih prostornih planova i razvojnih politika u turizmu.

Ključne riječi: turizam, plaža, prihvatni kapacitet, pandemija COVID-19, Mali Lošinj 
HRVATSKI

GEOGRAFSKI

GLASNIK

82/2,131-152 (2020.)

\section{Introduction}

The orientation of the development of summer tourism in the Mediterranean is often related to beaches, as one of the basic spatial resources of tourism. In the Mediterranean, the Adriatic Sea, and on the island of Lošinj, beaches are physical spaces of interest for different social groups with specific requirements. Definition and use of beaches as a natural, social, or economic resource is subjective and depends on individual interest (Kovačić et al., 2010). In a physical sense (for the purpose of determining bathing capacity), a sea beach could be defined as an area that extends from the start of the beach in the hinterland to the shoreline or contact with the sea. Considering the research on the formation and dynamics of changes in seashores and sea-level rise in the Adriatic Sea Rajčić et al., (2010); Faivre and Mićunović, (2017); and according to the characteristics of sea dynamics and geomorphological processes with anthropogenic influences in the area of the islands of Lošinj and Cres in geographically relevant time, the coastline shifts negligibly and does not affect the tourist valorization so, therefore, listed changes in this paper will not be considered.

The legal framework within which it is necessary to consider contemporary relations in the coastal area, and thus with regard to the area of beaches, is defined by legal acts. The fundamental legal ruling arising from these acts is that beaches in Croatia cannot be privately owned, rather they are a common $\operatorname{good}(\mathrm{NN}, 158 / 03 ; 100 / 04 ; 141 / 06 ; 38 / 09$; 123/11; 56/16).

Given the new circumstances related to the epidemiological situation caused by the outbreak of COVID-19 diseases and its general impact on tourism in the coming years, questions have been raised about how to reshape transit and logistical support, functional organisation of tourist sites, accommodation facilities, and the content of the tourism supply by implementing preventive anti-epidemic measures while at the same time maintaining the basic characteristics of touristic attractiveness.

The aim of the study presented in this paper was to determine the physical capacity of beaches in tourist microregions in the Town of Mali Lošinj, their real

\section{Uvod}

Usmjerenost razvoja ljetnoga turizma na području Mediterana često je vezana za plaže kao jedan od osnovnih turističkih prostornih resursa. Kako na Mediteranu u cjelini tako i na primjeru Jadranskoga mora i otoka Lošinja plaže su fizički prostor $\mathrm{u}$ interesu različitih društvenih skupina sa specifičnim zahtjevima te definiranje i korištenje plaže kao prirodnoga, društvenoga ili ekonomskoga resursa subjektivnoga je karaktera i ovisi o interesu pojedinoga aktera (Kovačić i dr., 2010). Iz fizičkoga kuta gledanja, za potrebe određivanja kupališnoga prihvatnog kapaciteta, morsku plažu bi se moglo definirati kao prostor koji se proteže od kopnenoga kupališno iskoristiva ruba plaže u zaleđu do obalne crte odnosno kontakta s morem. S obzirom na istraživanja oblikovanja i dinamike promjena morskih žala i rasta razine mora Jadranskoga mora Rajčić i dr., (2010); Faivre i Mićunović, (2017); te prema obilježjima dinamike mora i geomorfoloških procesa uz antropogene utjecaje na području otoka Lošinja i Cresa u geografski relevantnom vremenu obalna se crta zanemarivo pomiče i ne utječe na turističku valorizaciju te se zbog toga dalje u ovom radu navedene promjene neće se razmatrati.

Pravni okvir unutar kojega je potrebno razmatrati današnje odnose u obalnom prostoru, pa tako i s obzirom na prostor plaža, dan je putem zakonskih akata, a osnovo pravno svojstvo koje proizlazi iz ovih akata jest da plaže u Hrvatskoj ne mogu biti u režimu vlasništva, već su opće dobro (NN, 158/03; 100/04; 141/06; 38/09; $123 / 11 ; 56 / 16)$.

S obzirom na novonastale okolnosti vezane uz epidemiološku situaciju uzrokovanu pojavom COVID-19 bolesti te njezin opći utjecaj na turizam u daljnjim godinama postavljaju se pitanja kako preoblikovati prometno-logističku podršku, funkcionalnu organizaciju turističkih lokaliteta, smještajne kapacitete te sadržaj turističke ponude, a da provodeći preventivne protuepidemijske mjere, turizam istovremeno zadrži osnovna obilježja atraktivnosti.

Cilj istraživanja prikazanog ovim radom bio je utvrditi fizički prihvatni kapacitet plaža po turističkim mikroregijama na području Grada Malog 


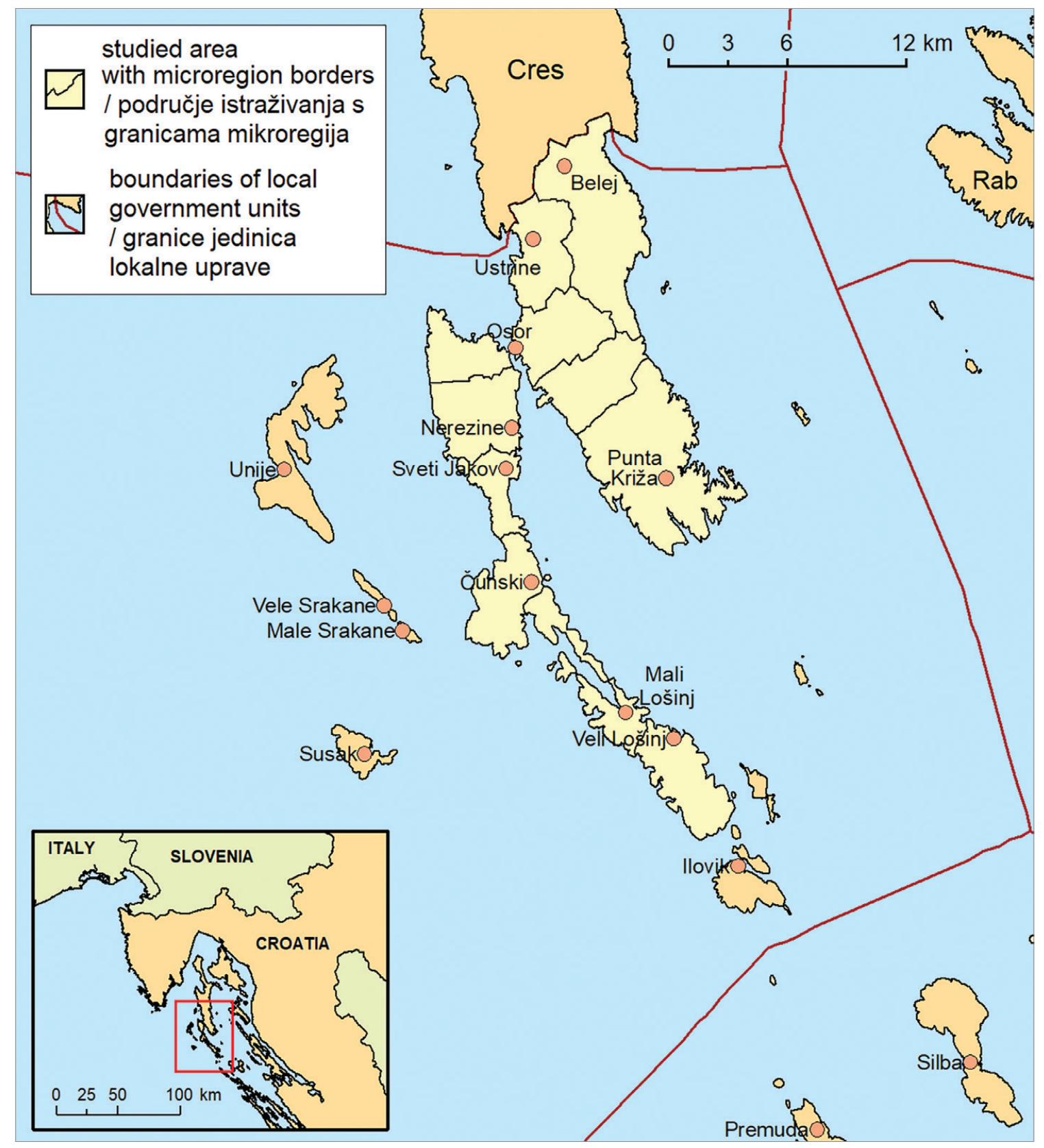

Assessment of acceptable tourism beach carrying capacity in both normal and COVID-19 pandemic conditions - case study of the Town of Mali Lošinj

Procjena prihvatljivog turističkog prihvatnog kapaciteta plaža u normalnim uvjetima i u uvjetima pandemije COVID-19 - studija slučaja Grada Malog Lošinja

Fig. 1 The study area

SI. 1. Pregledna karta istraživanoga prostora

load in the normal summer bathing season, and the assessment of acceptable tourist capacity on beaches under both normal conditions and under conditions of COVID 19 anti-epidemic measures. The investigated area covers most of the administrative unit of the Town of Mali Lošinj and is limited to the islands of Cres and Lošinj (Fig. 1), excluding the nearby
Lošinja, realnu opterećenost u uvjetima normalne ljetne kupališne sezone te procjenu prihvatljive turističke kupališne opterećenosti u normalnim uvjetima i u uvjetima primjene COVID-19 protuepidemijskih mjera. Istraživano područje obuhvaća većinu prostora administrativne jedinice Grad Mali Lošinj, a ograničeno je na prostor većih otoka Cres 
GEOGRAFSKI

GLASNIK

82/2,131-152 (2020.) smaller islands. According to the territorial organisation of the Republic of Croatia, the unit of local self-government of the Town of Mali Lošinj includes the southern third of the island of Cres and the entire island of Lošinj. Other smaller islands of the Lošinj/Cres Archipelago are excluded from the study area because they do not form a physically-connected area that is accessible to vehicles, which significantly limits the accessibility of their beaches.

The initial hypothesis of the paper is: $\mathrm{H}-0$ ) that the real carrying capacity of beaches in the area of the Town of Mali Lošinj in the conditions of the usual tourist season is close to the upper load limit. Further derived hypotheses that were tested and analysed during the research state: $\mathrm{H}-1$ ) that the real and effective carrying capacity of beaches is not temporally or spatially homogeneous; and $\mathrm{H}-2$ ) that the effective carrying capacity of beaches with the application of anti-epidemic measures decreases to the point that significant changes in tourism in the researched area become necessary.

The results of the work are primarily intended as an aid in sustainable spatial planning and the formulation of development strategies and policies in Croatia and the broader Mediterranean area.

\section{Methodology and previous research}

In order to gain insight into the state of the beaches of the islands of Cres and Lošinj that are included in the territorial unit of local self-government of the Town of Mali Lošinj, a combination of direct field and indirect cabinet methods was used. With direct field insight into accessibility and characteristics, beaches were classified into categories, while the length and area of beaches were measured by indirect cabinet measurement methods, using the online services of the State Geodetic Administration (Geoportal, 2020), the Institute for Physical Planning of Primorje-Gorski Kotar County (Geoportal PGŽ, 2020), and the Ministry of Agriculture (Arkod, 2020). Original statistical data regarding overnight stays for the administrative area of the Town of Mali Lošinj at the level of local self-government unit and by settlement were obtained from the Tourist Board of Mali Lošinj and the number of i Lošinj (sl. 1), što izuzima sve manje okolne otoke. Prema teritorijalnom ustrojstvu Republike $\mathrm{Hr}-$ vatske, jedinica lokalne samouprave Grada Malog Lošinja obuhvaća južnu trećinu otoka Cresa i cijeli otok Lošinj. Ostali manji otoci arhipelaga Lošinj i Cres izuzeti su s područja istraživanja jer ne čine fizički povezano područje dostupno cestovnim vozilima, što kupačima značajno ograničava dostupnost plaža.

Početna hipoteza $(\mathrm{H}-0)$ rada glasi da je realni prihvatni kapacitet plaža na prostoru jedinice lokalne samouprave Grad Mali Lošinj u uvjetima uobičajene turističke kupališne sezone blizu gornjih granica opterećenosti. Dalje izvedene hipoteze koje su se testirale prikupljanjem i analizom tijekom istraživanja jesu da $(\mathrm{H}-1)$ realni te efektivni prihvatni kapacitet plaža nije vremenski ni prostorno homogen te (H-2) efektivni prihvatni kapacitet plaža tijekom primjene protuepidemijskih mjera toliko se smanjuje da su nužne značajne promjene $u$ turizmu istraživanoga područja.

Rezultati rada ponajprije su namijenjeni kao pomoć pri održivom prostornom planiranju i oblikovanju razvojnih strategija i politika na području Hrvatske i širega prostora Mediterana.

\section{Metodologija i povijest istraživanja}

Kako bi se dobio uvid u stanje plaža otoka Cresa i Lošinja koje obuhvaća teritorijalna jedinica lokalne samouprave Grad Mali Lošinj, upotrijebljena je kombinacija izravnih terenskih i neizravnih kabinetskih metoda. Izravnim terenskim uvidom u dostupnost i obilježja plaže su razvrstane u kategorije, dok je neizravnim kabinetskim metodama mjerenja, putem mrežnoga servisa Državne geodetske uprave (Geoportal, 2020), Javne ustanove Zavoda za prostorno uređenje Primorsko-goranske županije (Geoportal PGŽ, 2020) i Ministarstva poljoprivrede (Arkod, 2020), izmjerena dužina i površina plaža. Izvorni statistički podatci o turističkim noćenjima $\mathrm{za}$ administrativni prostor Grada $\mathrm{Ma}-$ $\log$ Lošinja na razini jedinice lokalne samouprave i niže po naseljima dobiveni su od Turističke zajednice Grada Malog Lošinja te je broj stanovnika na prostoru jedinice lokalne samouprave Grada 
inhabitants of the administrative unit of Mali Lošinj was obtained from the Croatian Bureau of Statistics.

A review of the literature shows that the issue of determining the carrying capacity of beaches as part of a broader concept of sustainable tourism development mainly appears in the works of the last two to three decades: Magaš and Smolčić Jurdana (1999); Da Silva (2002); Micallef et al. (2004); Valdemoro and Jimenez (2006); Ariza et al, (2008); Kovačić et al., (2010); Kovačić and Komać (2011); Zacarias et al. (2011); Silva and Ferreira (2013); Fernadez and Bertola (2015); Chen and Teng (2016); Huamatinco (2016); Rodella et al. (2017); Carić and Jakelić (2018); Rudan and Krstinić Nižić (2018); Serrano et al. (2018); Cabezas (2019); Corbau et al. (2019); and Rodella et al. (2020). In addition to these papers, it is necessary to highlight the manuals UNEP / PAP, (1997) and PAP / RAC, (2003) and the book Beach Management - Principles and Practice Williams and Micallef, (2009). Of particular importance for this work are the documents related to determining the carrying capacity of beaches in the administrative area of the Town of Mali Lošinj: Sustainable Beach Management in Croatia Guidelines and Priority Actions (2010); Spatial Plan of Primorje-Gorski Kotar County (2013); National Programme for Management and Regulation of Sea Beaches - Action Plan (2014); Regional Programme of Arrangement and Management of Sea Beaches in Primorje-Gorski Kotar County (2015).

After reviewing the relevant scientific literature in further research of the case study of carrying capacity of beaches of the Town of Mali Lošinj, methodological guidelines were used in the form of four research phases taken from basic research of sustainable management of tourist beach resources listed in UNEP / PAP (1997) and Magaš and Smoličić Jurdana (1999): first phase-collecting documentation; second phase-analysis; third phase-tourism development options; and fourth phase-calculation of beach capacity.

During the literature review process, the method of determining physical carrying capacity (PCC) was chosen, which is converted into real carrying capacity (RCC) using correction factors, and in some areas and under specific conditions it is converted into effective carrying capacity (ECC).
Malog Lošinja preuzet od Državnoga zavoda za statistiku.

Pregledom literature uočeno je da se problematika određivanja prihvatnoga kapaciteta plaža kao dijela širega koncepta održivoga razvoja turizma uglavnom pojavljuje u radovima posljenjih dva do tri desetljeća: Magaš i Smolčić Jurdana (1999); Da Silva (2002); Micallef i dr. (2004); Valdemoro i Jimenez (2006); Ariza i dr. (2008); Kovačić i dr. (2010); Kovačić i Komać (2011); Zacarias i dr. (2011); Silva i Ferreira (2013); Fernadez i Bertola (2015); Chen i Teng (2016); Huamatinco (2016); Rodella i dr., (2017); Carić i Jakelić (2018); Rudan i Krstinić Nižić (2018); Serrano i dr. (2018); Cabezas (2019); Corbau i dr. (2019); Rodella i dr. (2020). $\mathrm{Uz}$ navedene radove potrebno je istaknuti i priručnike UNEP/PAP, (1997) i PAP/RAC, (2003), knjigu Beach Management - Principles and Practice Williams i Micallef, (2009). Za ovaj rad od posebne su važnosti i planski dokumenti vezani za određivanje prihvatnoga kapaciteta plaža na području Grada Malog Lošinja: Održivo upravljanje plažama u Hrvatskoj-smjernice i prioritetne akcije (2010); Prostorni plan Primorsko-goranske županije (2013); Nacionalni program upravljanja i uređenja morskib plaža - akcijski plan (2014); Regionalni program uređenja i upravljanja morskim plažama na području Primorsko-goranske županije (2015).

Nakon pregleda relevantne znanstvene literature u daljnjem istraživanju studije slučaja određivanja prihvatnoga kapaciteta plaža Grada Malog Lošinja koristile su se metodološke smjernice u obliku četiri istraživačke faze preuzete iz temeljnih istraživanja održivoga gospodarenja turističkih plažnih resursa navedene u UNEP/PAP (1997) i Magaš i Smolčić Jurdana (1999): prva faza - prikupljanje dokumentacije; druga faza - analiza; treća faza - opcije razvoja turizma; četvrta faza - izračun prihvatnoga kapaciteta plaža.

Tijekom pregleda literature izabrana je metoda određivanja fizičkoga prihvatnog kapaciteta plaža (phisical carrying capacity - PCC) koja se upotrebom korekcijskih faktora pretvara u realni prihvatni kapacitet plaža (real carrying capacity - RCC), a na pojedinim područjima i u specifičnim uvjetima pretvara se u efektivni prihvatni kapacitet plaža (effective carrying capacity - ECC).
Assessment of acceptable tourism beach carrying capacity in both normal and COVID-19

pandemic conditions - case study of the

Town of Mali Lošinj

Procjena prihvatljivog turističkog prihvatnog kapaciteta plaža u normalnim uvjetima i u uvjetima pandemije COVID-19 - studija slučaja Grada Malog Lošinja 
Under normal conditions, the rule is that:

$\mathrm{PCC}>\mathrm{RCC} \geq \mathrm{ECC}$

\section{$\mathrm{PCC}=\mathrm{A} / \mathrm{Au} \times \mathrm{Rf}$}

A - available area of the beach for tourist usage (physical suitable surface of the beach)

Au - area required for each person on the beach (intensity or desired comfort)

$\mathbf{R f}$ - rotation factor, is calculated as an estimate of the use of hours per day of the beach area. In this research, an $\mathrm{Rf}$ value of 2 was used (during the day the availability of beaches within the tourist season is $12 \mathrm{~h}$, and it is estimated that any given parcel of beach area is used by an average of two people a day, or that the average stay per person on the beach is 6 hours).

$\mathrm{RCC}$ is calculated with correction factors that are determined at the level of the calendar year by the limited duration of the bathing season and due to the climatic characteristics of the destination, weather conditions within the bathing season (rainy days, days of high winds, temperature, and insolation). The influence of flora and fauna (occurrence of sea blooms, jellyfish or similar organisms, concentrations of pollen) was also taken into account. In addition to natural limiting factors in some localities, anthropogenic impact (e.g. high faecal concentrations in bathing areas) may be limiting in certain time periods or localities.

In order to determine the possible duration of the bathing season (as the most important correction factor) on natural beaches in the Town of Mali Lošinj with regard to the climatic characteristics of the area, the data of average monthly values and extremes for the Mali Lošinj meteorological station in the period of 1961 to 2018 (DHMZ, 2020) were analysed. It was observed that, according to favourable temperature characteristics on a monthly basis, precipitation, wind frequency and speed, and insolation, the bathing period lasts from June to September-roughly 122 days (Tab. 1). The duration of the bathing season from June to September has also been confirmed by scientific papers from neighbouring areas in the Adriatic Sea (Rodella et al., 2020) and in the Mediterranean in general (Corbau et al., 2019).
U normalnim uvjetima vrijedi pravilo da je: $\mathrm{PCC}>\mathrm{RCC} \geq \mathrm{ECC}$

$$
\mathrm{PCC}=\mathrm{A} / \mathrm{Au} \times \mathrm{Rf}
$$

A - raspoloživa površina na plaži za turističku upotrebu (fizički odgovarajuća površina plaže)

Au - površina potrebna po osobi na plaži (intenzitet željene udobnosti)

Rf - faktor rotacije, računa se kao procjena korištenja sati po danu plažne površine. U ovom istraživanju upotrijebljen je $\mathrm{Rf}$ vrijednosti 2 (tijekom dana raspoloživost plaža unutar turističke sezone iznosi 12 sati, a procijenjeno je da istu plažnu površinu koriste prosječno dvije osobe dnevno, odnosno prosječan boravak po osobi na plaži je 6 sati).

RCC se računa uz korekcijske faktore koji su na razini kalendarske godine određeni ograničenošću trajanja kupališne sezone zbog klimatskih obilježja destinacije te uže zbog vremenskih prilika unutar kupališne sezone (broj kišnih dana, jakost vjetra u pojedinim danima, temperatura, insolacija), a uz atmosferske prilike nužno je ne zanemariti i utjecaj flore i faune (pojave cvjetanja mora, pojave meduza ili sličnih organizama, dani s velikom koncentracijom peludi...). Uz prirodne ograničavajuće čimbenike, na nekim lokalitetima i antropogeni utjecaj (proboj i utjecaj fekalnih voda...) u pojedinim razdobljima ili lokalitetima može biti ograničavajući.

Kako bi se odredilo moguće trajanje kupališne sezone (najvažniji korekcijski faktor) na prirodnim plažama na području Grada Malog Lošinja s obzirom na klimatska obilježja prostora, analizirani su podatci srednjih mjesečnih vrijednosti i ekstrema za meteorološku postaju Mali Lošinj u razdoblju od 1961. do 2018. godine (DHMZ, 2020). Uočeno je da se na mjesečnoj razini prema povoljnim temperaturnim obilježjima, količini oborina, učestalosti i brzini vjetra te insolaciji izdvaja razdoblje od lipnja do rujna, odnosno 122 dana (tab. 1). Razdoblje trajanja kupališne sezone od lipnja do rujna potvrđuju i znanstveni radovi sa susjednih područja na Jadranskom moru (Rodella i dr., 2020) i Mediteranu općenito (Corbau i dr., 2019). 
Tab. 1 Selected average monthly values and extremes for the meteorological station Mali Lošinj from 1961 to 2018

Tab. 1. Izdvojene srednje mjesečne vrijednosti i ekstremi za meteorološku postaju Mali Lošinj od 1961. do 2018. godine

\begin{tabular}{|c|c|c|c|c|}
\hline Climatic elements / Klimatski elementi & $\begin{array}{l}\text { June } \\
\text { / Lipanj }\end{array}$ & $\begin{array}{l}\text { July } \\
\text { / Srpanj }\end{array}$ & $\begin{array}{l}\text { August } \\
\text { / Kolovoz }\end{array}$ & $\begin{array}{l}\text { September } \\
\text { / Rujan }\end{array}$ \\
\hline Mean daily temperature / Srednja dnevna temperatura $\left({ }^{\circ} \mathrm{C}\right)$ & 21.9 & 24.5 & 24.3 & 20.5 \\
\hline Number of hot days / Broj vrućih dana $\left(>30^{\circ} \mathrm{C}\right)$ & 4.0 & 12.0 & 11.0 & 1.0 \\
\hline Number of warm days / Broj toplih dana $\left(\geq 25^{\circ} \mathrm{C}\right)$ & 18.0 & 28.0 & 27.0 & 13.0 \\
\hline Maximum temperatures / Maksimalne temperature $\left({ }^{\circ} \mathrm{C}\right)$ & 35.6 & 37.2 & 39.0 & 32.4 \\
\hline Insolation (hours) / Insolacija (sati) & 322.7 & 363.4 & 330.5 & 245.4 \\
\hline Number of days with rain / Broj dana s kišom & 8.0 & 6.0 & 6.0 & 8.0 \\
\hline Precipitation / Količina oborina & 57.6 & 37.6 & 62.6 & 101.3 \\
\hline
\end{tabular}

Source / Izvor: DHMZ (2020)

The RCC capacity of the beach is associated in many studies with the sustainability of the beach not only as a social space of interaction but also from the environmental aspect, so the PCC is corrected by using coefficients to put the spatial load within the level of beach use intensity that ensures its sustainability. Regarding the example of the case study of beaches from the area of the Town of Mali Lošinj, the correction factor used was $21.5 \%$ (Cf $=0.785$ ), which was taken from the methodology of the National Programme for Management and Regulation of Sea Beaches (2014) (Tab. 7).

In the context of RCC beaches, the public health aspect is very significant (sanitary quality of sea beaches). In the usual conditions of the summer tourist season, for example, the normally rare occurrence of increased concentration of pathogenic bacteria in the sea can occur in some localities as a consequence of sewage system problems (Sekulić and Fuks, 1999). In such cases, the beaches are most often marked and closed until the issue is resolved. Such phenomena are not common in the study area and are not taken into account in further consideration. Due to the emergence of public health measures to combat the COVID-19 pandemic during the
RCC kapacitet plaže se u mnogim studijama povezuje s održivošću plaže ne samo kao društvenoga prostora interakcije već i u ekološkom aspektu pa se PCC korigira upotrebom koeficijenata da bi se opterećenost prostora stavila unutar razine intenziteta korištenja plaže koji osigurava njezinu održivost. $\mathrm{Na}$ primjeru studije slučaja plaža s prostora Grada Malog Lošinja za korekcijski faktor uzet je $21,5 \%(\mathrm{Cf}=0,785)$ koji je preuzet iz metodologije Nacionalnoga programa upravljanja i uređenja morskih plaža 2014. (tab. 7).

U kontekstu RCC plaže javnozdravstveni aspekt vrlo je važan (sanitarna kvaliteta morskih plaža). U uobičajenim uvjetima kupališne turističke sezone na nekim lokalitetima moguća je primjerice rijetka pojava povećane koncentracije patogenih bakterija u moru kao posljedica pojave fekalnih voda (Sekulić i Fuks, 1999). U takvim se slučajevima plaže najčešće obilježavaju i stavljaju izvan upotrebe. Ovakve pojave nisu uobičajene na istraživanom području pa u daljnjem razmatranju nisu uzete u obzir. Zbog pojave javnozdravstvenih mjera za suzbijanje pandemije COVID-19 za kupališnu sezonu 2020. u ovom
Assessment of acceptable tourism beach carrying capacity in both normal and COVID-19 pandemic conditions - case study of the Town of Mali Lošinj

Procjena prihvatljivog turističkog prihvatnog kapaciteta plaža u normalnim uvjetima i u uvjetima pandemije COVID-19 - studija slučaja Grada Malog Lošinja 
2020 summer tourism season, a projection of the implementation of preventive measures on the real capacity on beaches was carried out (Tab. 4 and 5).

ECC is calculated as the final capacity of a beach area as the result of all previous input variables, with the aim of shaping the capacity of the beach in physical planning or management aspects of development, specialisation, branding, etc. for a given destination, tourism site, or individual beach. Contemporary trends in profiling and branding of individual tourism destinations increasingly indicate the theme of beaches, which, given the expectations of tourists regarding beaches, also affects the determination of available beach area per user (Regional programme of Arrangement and Management of Sea Beaches in Primorje-Gorski Kotar County, 2015).

Prior to the process of differentiating mapped beaches for the case study of the Town of Mali Lošinj, a review of scientific and professional literature was performed and relevant methods of classifying and typifying beaches in the Mediterranean area were analysed. Micallef et al. (2004) singled out the Bathing Area Registration \& Evaluation (BARE) methodology as a relevant method for determining the type of beaches in Croatia. BARE methodology uses the following parameters: safety on the beach (equipment and lifeguards); sea quality (institutional control); facilities (sanitary, hospitality, and recreational facilities); coastal landscape (attractiveness and functionality); and cleanliness of the beach (waste on the beach). Furthermore, BARE singles out five beach types: resort; urban; village; rural; and remote. BARE methodology was also used for beach typification in the following studies: Guidelines for Carrying Capacity Assessment for Tourism in Mediterranean Coastal Areas (1997) and Guide to Good Practices in Tourism Carrying Capacity Assessment (2003).

Following the logic of the spatial narrowing of the research area in the review of scientific-professional literature for this research, the approach to beach typification in the Regional Programme of Arrangement and Management of Sea Beaches in Primorje-Gorski Kotar County (2015) resulted in the classification of beaches into two basic groups with subgroups: 1 . natural beaches (1.1 remote, 1.2 rural) and 2. arranged beaches (2.1 local, 2.2 urban, 2.3 beaches of tourist complexes). Similarly, by the logic radu izvršena je projekcija provedbe preventivnih mjera realnoga prihvatnog kapaciteta na plažama (tab. 4 i 5).

ECC se računa kao konačni kapacitet nekoga plažnog prostora koji je rezultat svih prethodnih ulaznih varijabla uz slobodnu mogućnost oblikovanja kapaciteta plaže u prostornoplanskom ili menadžerskom aspektu razvoja, specijalizacije, brendiranja destinacije, turističkoga lokaliteta ili još uže neke konkretne plaže. Suvremeni trendovi profiliranja i brendiranja pojedinih turističkih destinacija sve više upućuju na tematizaciju plaža koja s obzirom na očekivanja kupača na tako izdvojenim plažama utječe i na određivanje raspoložive plažne površine po korisniku (Regionalni program uređenja i upravljanja morskim plažama na području Primorsko-goranske županije, 2015).

Prije postupka diferenciranja kartiranih plaža za studiju slučaja Grada Malog Lošinja pregledana je znanstvena i stručna literatura te su izdvojene relevantne metode klasificiranja i tipiziranja plaža na području Mediterana. Kao relevantna metoda za odredivanje tipa plaža izdvojena je metodologija Bathing Area Registration \& Evaluation (BARE), koju su po prvi put upravo na prostoru Hrvatske upotrijebili Micallef i dr. (2004). BARE metodologija upotrebljava sljedeće parametre: sigurnost na plaži (oprema i spasioci), kakvoća mora (institucionalna kontrola), sadržaji (sanitarni, ugostiteljski i rekreacijski sadržaji), obalni krajolik (atraktivnost i funkcionalnost) i čistoća plaže (otpad na plaži) te izdvaja pet tipova plaža: resort, urban, village, rural and remote. Za tipizaciju plaža BARE metodologija također se koristila u studijama: Guidelines for Carrying Capacity Assessment for Tourism in Mediteranean Coastal Areas (1997). i Guide to Good Practice in Tourism Carrying Capacity Assessment (2003).

Slijedeći logiku prostornoga sužavanja istraživanog područja, u pregledu znanstveno-stručne literature za ovo istraživanje analiziran je i pristup tipizaciji plaža u Regionalnom programu uređenja i upravljanja morskim plažama na području Primorsko-goranske županije (2015), u kojem su plaže razvrstane u dvije osnovne skupine s podskupinama: 1 . prirodne plaže (1.1 udaljene, 1.2 ruralne), 2. uređene plaže (2.1 mjesne, 2.2 urbane, 2.3 plaže turističkih kompleksa). Logikom prostornoga sužavanja 
of spatial narrowing of bathing destinations similar to the studied area, the case study Tourism Supply of the Municipality of Lovran in Primorje-Gorski Kotar County was singled out, which includes the analysis Beaches as the Basis of the Tourism Supply of Lovran (Rudan and Krstinić Nižić, 2018). Classification of beaches in this case study WAs also done according to BARE methodology, adjusted to the needs of the market according to their accessibility and coastal scenery (Rudan and Krstinić Nižić, 2018).

We selected papers that deal with Beach Crowding Index (BCI) from relevant literature for use along with BARE methodology of beach classification, in order to implement not only the physical carrying capacity but also the social element of bathers' expectations (which vary depending on the beach) into the case study. The analysis of the functional load and the subjective experience of the quality of the total beach area for the Mediterranean was developed by Ariza et al. (2007; 2008), who introduced the Beach Quality Index (BQI) (Williams and Micallef, 2009). Not to be confused with BQI, the Beach Crowding Index has developed since its introduction and Serrano et al. (2018) state that BCI is a tool for assessing Social Carrying Capacity which synthetises the type and size of a given beach, and the number of users and their location on the beach. The BCI should be viewed as an analytical and functional tool used to ascertain the optimal level of comfort on a given beach. Bathers often avoid overcrowded beaches, especially in non-urban areas, because they are usually seeking peace, tranquillity, and sometimes isolation. Based on historical research, surveys, and fieldwork, Serraano et al., (2018) lists the following categories for BCI: 1) poor $\leq 2 \mathrm{~m} 2$ / bather; 2) acceptable 2.1-2.5 $\mathrm{m} 2$ / bather; 3) good 2.6-3.0 m2 / bather; and 4) very good $\geq 3.1 \mathrm{~m} 2$ / bather. The BCI scores should not be understood as the maximum number of bathers a given beach can hold in a given area to obtain a given degree of comfort, rather as a reference threshold that allows people to enjoy the beach without its quality falling below a suitable standard (Serrano et al., 2018).

A review of scientific papers, studies and planning documents dealing with the issue of projection and determination of carrying capacity of beaches in the world, especially in the Mediterranean, revealed scientific inconsistency in terms of standards regarding the kupališnih destinacija sličnih proučavanom području izdvojena je studija slučaja Tourism offering of the Municipality of Lovran unutar Primorsko-goranske županije koja obuhvaća i analizu Beaches as the Basis of the Tourism Offering of Lovran (Rudan i Krstinić Nižić, 2018). Klasifikacija plaža u toj studiji slučaja također je načinjena prema BARE metodologiji koja je prilagođena potrebama korisnika te prema dostupnosti i obalnom krajoliku (Rudan i Krstinić Nižić, 2018).

Uz BARE metodologiju klasificiranja plaža, kako bi se u studiji slučaja implementirali ne samo fizički prihvatni kapacitet već i socijalni element očekivanja samih kupača koji nije jednak na svim plažama, iz znanstvene i stručne literature izdvojeni su radovi koji razmatraju indeks zagušenosti plaža (Beach Crowding Indeks - BCI). Analizu funkcionalne opterećenosti, ali i subjektivnoga doživljaja kvalitete ukupnoga plažnog prostora za prostor Mediterana započeli su razvijati Ariza i dr. (2007; 2008) uvodeći indeks kvalitete plaža (Beach Quality Indeks) Williams i Micallef (2009). Nadalje, BCI se razvio u idućim godinama te Serrano i dr. (2018) navode da je BCI alat za procjenu prihvatnoga kapaciteta plaža koji sintetizira tip, veličinu, broj korisnika i njihovu lokaciju unutar plaže. BCI treba promatrati kao analitički i funkcionalni alat u svrsi ostvarivanja razine udobnosti na plažama. Kupači često izbjegavaju zagušene plaže, posebice ako su one ruralnoga tipa jer obično traže mir, tišinu a ponekad i izolaciju. $\mathrm{Na}$ osnovi povijesti istraživanja, provedenih anketa $\mathrm{i}$ terenskoga rada Serrano i dr. (2018). navode sljedeće kategorije za BCI: 1) loše $\leq 2 \mathrm{~m}^{2}$ po kupaču; 2) prihvatljivo 2,1-2,5 $\mathrm{m}^{2}$ po kupaču; 3) dobro 2,6 - 3,0 $\mathrm{m}^{2}$ po kupaču; 4) jako dobro $\geq 3,1 \mathrm{~m}^{2}$ po kupaču. BCI vrijednosti ne bi trebale biti tumačene kao maksimalne vrijednosti broja kupača po jedinici površine na određenoj plaži, već kao referentni prag koji omogućava korisnicima plaže da imaju određenu standardiziranu razinu ugode (Serrano i dr., 2018).

Pregledom znanstvenih radova, studija i planskih dokumenata koji se bave problematikom projekcije i određivanja prihvatnoga kapaciteta plaža u svijetu, a posebice na području Mediterana, uočena je znanstvena neusuglašenost standarda glede vrijednosti
Assessment of acceptable tourism beach carrying capacity in both normal and COVID-19

pandemic conditions - case study of the

Town of Mali Lošinj

Procjena prihvatljivog turističkog prihvatnog kapaciteta plaža u normalnim uvjetima i u uvjetima pandemije COVID-19 - studija slučaja Grada Malog Lošinja 
GEOGRAFSKI

GLASNIK

82/2,131-152 (2020.) value of the minimum unit area, which varies from 3 to $30 \mathrm{~m}^{2}$ per bather. For example, Ariza et al. (2008) use the measurement of maximum sustainable density on beaches of $4 \mathrm{~m}^{2}$ per bather in their carrying capacity study of Catalonia's beaches, Rodella et al. (2020) state values of $5 \mathrm{~m}^{2}$ and $8 \mathrm{~m}^{2}$ per bather in their case study of the Venetian lagoon, and planning documents in the Republic of Croatia use values ranging from $5 \mathrm{~m}^{2}$ to $30 \mathrm{~m}^{2}$ per bather ${ }^{1}$. The reason for such large oscillations in area is the consequence of various physical characteristics of beaches (sandy, pebbly, rocky) and of available beach areas, which limit the number of bathers and earning potential, while on the other hand, a significant factor is contentment and the targeted level of quality of service, i.e. achieving comfort on the beach. In a number of papers, however, it has been observed that the value of $5 \mathrm{~m}^{2}$ per bather is repeated (Valdemoro and Jimenez, 2006; Zacarias et al., 2011; Fernadez and Bertola, 2015, Serrano et al., 2018; Cabezas, 2019; Rodella et al., 2020), which could be taken as the normal standard estimated value of beach area per bather.

After consulting various methodological guidelines, classifying beaches, and determining the acceptable surface value per bather, an assessment of the physical carrying capacity of beaches (reception capacity) was carried out and adapted to the research area. Considering the lack of homogeneity of beach characteristics, primarily according to the type of substrate, availability, and user expectations within the administrative area of the Town of Mali Lošinj (shown in Tab. 1 and 2) when calculating the carrying capacity, differentiation was performed according to observed specific characteristics. This paper uses the basic methodology of beach classification according to BARE typing system with modifications according to the integrated characteristics of beaches in the area of the Town of Mali Lošinj in the context of observed specifics from field observations by type of beach.

The beaches of the research area of the islands of Cres and Lošinj have been divided into three categories as shown on Fig. 2, 3 and 4.

\footnotetext{
1 National Programme of Management and Arrangement of Sea Beaches - Action Plan (2014), Spatial plan of Primorje-Gorski Kotar County (2013), Regional Programme of Arrangement and Management of Sea Beaches in the Area of Primorje-Gorski Kotar County (2015).
}

minimalne jedinične površine koja u različitim studijama varira od 3 pa do $30 \mathrm{~m}^{2}$ po kupaču. Primjerice, Ariza i dr. (2008) u studiji prihvatnoga kapaciteta plaža Katalonije koriste mjeru maksimalne održive gustoće na plažama od $4 \mathrm{~m}^{2}$ po kupaču, Rodella i dr. (2020) navode u studiji slučaja Venecijanske lagune vrijednosti od 5 i $8 \mathrm{~m}^{2}$ po kupaču, planski dokumenti u Republici Hrvatskoj koriste vrijednosti od 5 do $30 \mathrm{~m}^{2}$ po kupaču. ${ }^{1}$ Razlog tako velikim oscilacijama u površini posljedica je s jedne strane različitih fizičkih obilježja samih plaža (pješčane, šljunčane, stjenovite...), ali i raspoložive plažne površine, koje limitiraju broj kupača odnosno potencijalu zaradu, dok je s druge strane važan čimbenik sadržaj i razina ciljane kvalitete usluge odnosno postizanje ugodnosti na plažama. Ipak, u većem broju radova ponavlja se vrijednost od $5 \mathrm{~m}^{2}$ po kupaču (Valdemoro i Jimenez, 2006; Zacarias i dr., 2011; Fernadez i Bertola, 2015; Serrano i dr., 2018; Cabezas, 2019; Rodella i dr., 2020) koja bi se mogla uzeti kao uobičajena standardna procijenjena vrijednost površine plaže po kupaču.

Nakon konzultiranja različitih metodoloških smjernica, pristupa klasificiranju plaža i određivanju prihvatljive površinske vrijednosti po kupaču izrađena je procjena fizičkoga prihvatnog kapaciteta plaža (prihvatnoga kapaciteta) prilagođena istraživanom području Grada Malog Lošinja. S obzirom na nehomogenost obilježja plaža, prvenstveno prema tipu podloge, dostupnosti i očekivanju korisnika unutar administrativnog područja Grada Malog Lošinja (prikazano u tab. 1 i 2) pri izračunu prihvatnoga kapaciteta pristupilo se njihovu diferenciranju prema uočenim specifičnim obilježjima. U ovom radu korištena je osnovna metodologija klasifikacije plaže prema BARE sistemu tipizacije s modifikacijama koje su upotrijebljene prema objedinjenim obilježjima plaža na području Grada Malog Lošinja u kontekstu uočenih specifičnosti iz terenskih zapažanja po pojedinim tipovima plaža.

Plaže istraživanoga područja otoka Cresa i Lošinja podijeljene su u tri kategorije kako je prikazano na sl. 2, 3 i 4 .

\footnotetext{
1 Nacionalni program upravljanja i uređenja morskih plaža - akcijski plan (2014), Prostorni plan Primorsko-goranske županije (2013), Regionalni program uređenja i upravljanja morskim plažama na području Primorsko-goranske županije (2015).
} 
Fig. 2 Beaches within settlements (tourist settlements, urban, and local beaches): the basic feature of these areas is a high degree of anthropogenic modification of the beach itself and its hinterland SI. 2. Plaže unutar naselja (turistička naselja, urbane i mjesne plaže): osnovno je obiliežje ovih prostora viši stupanj antropogene modifikacije plaže i njezina zaleđa

Fig. 3 Beaches outside the settlement (rural) accessible from the mainland: the main features of these beaches are their pristine state or low degree of anthropogenic impact and the accessibility of beaches from the mainland

SI. 3. Plaže izvan naselja (ruralne) dostupne s kopnene strane: osnovna su obilježja ovih plaža izvornost ili niži stupanj antropogenoga utjecaja i dostupnost plaža s kopnene strane

Fig. 4 Beaches accessible only from the sea (remote): the main feature of these beaches is inaccessibility from the mainland (due to distance or steep slopes)

SI. 4. Plaže dostupne samo morske strane (udaljene): osnovno je obilježje ovih plaža nedostupnost s kopnene strane lzbog udaljenosti ili strmih padina u zaleđu)
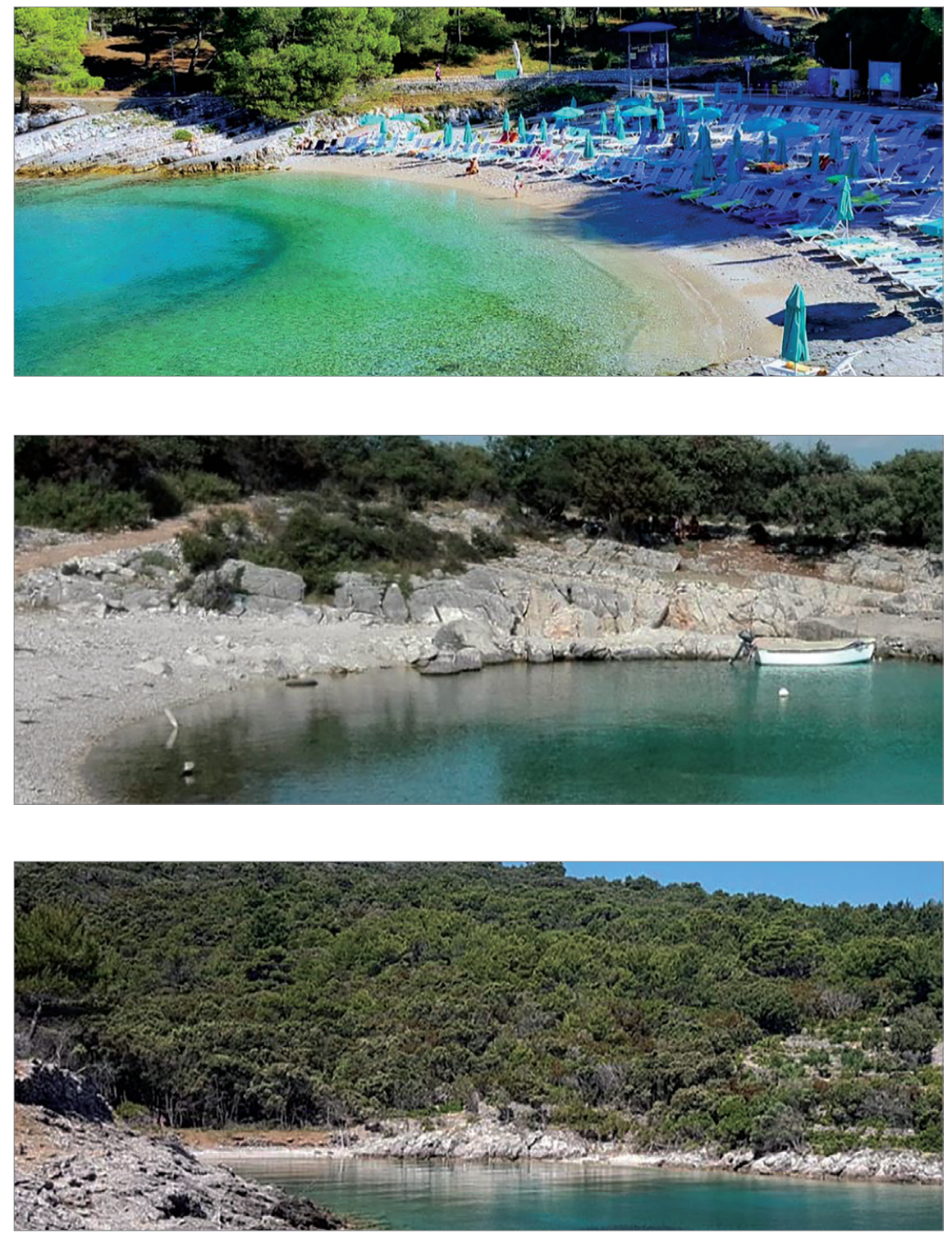

Assessment of acceptable tourism beach carrying capacity in both normal and COVID-19 pandemic conditions - case study of the Town of Mali Lošinj

Procjena prihvatljivog turističkog prihvatnog kapaciteta plaža u normalnim uvjetima i u uvjetima pandemije COVID-19-studija slučaja Grada Malog Lošinja

With regard to the categorisation of beaches, a separate area required for each person on the beach $\mathrm{Au})$ was taken in the analysis for each category in the calculation of PCC beaches. The reason for this procedure is for comparison of the criteria of physical carrying capacity of beaches and the criteria of needs and expectations of bathers. Thus, the Au for beaches within the settlement is $5 \mathrm{~m}^{2}(2 \mathrm{~m} \times 2.5 \mathrm{~m})$, for beaches outside settlements that are accessible from the mainland $\mathrm{Au}$ is $8 \mathrm{~m}^{2}(2 \mathrm{mx} 4 \mathrm{~m})$, and for remote beaches accessible only from the sea $\mathrm{Au}$ is $16 \mathrm{~m}^{2}(4 \mathrm{mx} 4 \mathrm{~m})$. Regardless of the fact that beach areas in tourist destinations are often treated uni-
S obzirom na kategorizaciju plaža u analizi je za svaku pojedinu kategoriju uzet zasebni kriterij jedinične površine u izračunu PCC plaža. Razlog je za ovakav postupak usporedna upotreba kriterija fizičkoga prihvatnog kapaciteta plaža i kriterija potreba, odnosno očekivanja kupača. Tako je određena jedinična površina po kupaču za plaže unutar naselja 5 $\mathrm{m}^{2}(2 \mathrm{~m} \times 2,5 \mathrm{~m})$, za plaže izvan naselja dostupnih s kopna $8 \mathrm{~m}^{2}(2 \mathrm{mx} 4 \mathrm{~m})$, a za udaljene plaže dostupne samo s morske strane $16 \mathrm{~m}^{2}$ (4 m x $\left.4 \mathrm{~m}\right)$. Bez obzira na to što se površine plaža u studijama prihvatnoga kapaciteta turističkih destinacija često tretiraju uni- 
GEOGRAFSKI

GLASNIK

82/2,131-152 (2020.) formly ${ }^{2}$, such a calculation would not be realistic for a specific example of the carrying capacity of beaches in the study area because they are rather diverse in terms of accessibility and substrate (rocky, mixed, or pebble type). The carrying capacity of rock-type beaches, which are usually outside settlements, is lower due to the characteristics of the surface, but also due to the fact that places to enter the sea can be hard to find. An important reason for increasing $\mathrm{Au}$ on beaches that are not in settlements is bathers' expectations of privacy.

\section{Results and discussion}

After direct fieldwork and cabinet mapping, the total mapped physical area of beaches in the researched area was $132,050 \mathrm{~m}^{2}$. In order to get a better insight into possible physical, real, and effective carrying capacity of the area of the Town of Mali Lošinj was divided into five microregions (Fig. 1) and the actual load of beaches during the tourist bathing season in 2018 was calculated (Tab. 2).

The analysis of the estimated physical reception capacity of the beaches of the researched area shows that the microregions Mali Lošinj and Nerezine stand out according to the mapped areas with significant beach capacity (Tab. 3). These two microregions have been at the forefront in the development of tourism in quantitative terms in recent decades, but in terms of the load on beach areas it is necessary to point out the great difference in the structure of bathers. The Mali Lošinj microregion is a demographic centre with almost 17 times more inhabitants than the Nerezine microregion, also Mali Lošinj is a centre with larger hotel capacities, while Nerezine is oriented towards two smaller tourist resorts, camping tourism, apartment rentals, and weekend facilities. Among other microregions, the predominant camping services in Punta Križa should also be mentioned.

\footnotetext{
2 The most common uniform treatment of beaches in literature: Valdemoro and Jimenez (2006), Jurinčič (2009), Zacarias et al. (2011), Silva and Ferreira (2013), Rodella et al. (2017), Serrano et al. (2018), Cabezas (2019), Rodella et al. (2020) is caused by a uniform substrate.
}

formno, ${ }^{2}$ na konkretnom primjeru prihvatnoga kapaciteta plaža istraživanoga područja takav izračun ne bi bio realan jer su plaže na istraživanom području većinom raznovrsne po obilježjima dostupnosti i podloge (stjenovitoga, miješanoga ili šljunčanoga tipa). Prihvatni kapacitet plaža stjenovitoga tipa, koje su najčešće izvan naselja, manja je zbog samih obilježja podloge, ali i zbog otežana ulaza u more. Važan razlog za povećavanje jedinične površine na plažama koje nisu u naseljima jesu i očekivanja privatnosti kupača na takvim tipovima plaža.

\section{Rezultati i rasprava}

Nakon izravnoga terenskog rada i kabinetskoga kartiranja neizravnim putem izračunata je ukupna kartirana fizička površina plaža istraživanoga područja od $132050 \mathrm{~m}^{2}$ te je prostor teritorijalne jedinice Grad Mali Lošinj podijeljen na pet mikroregija (sl.1.) kako bi se dobio bolji uvid u stanje mogućega fizičkog, realnog i efektivnoga prihvatnog kapaciteta te stvarne opterećenosti plaža tijekom turističke kupališne sezone 2018. godine (tab. 2).

Analizom procijenjenoga fizičkog prihvatnog kapaciteta plaža istraživanoga područja uočava se da se po kartiranim površinama sa značajnim plažnim kapacitetom izdvajaju mikroregije Mali Lošinj i Nerezine (tab. 3). Upravo su te dvije mikroregije u kvantitativnom smislu u razvoju turizma i prednjačile zadnjih desetljeća, ali je glede opterećenja plažnih površina potrebno istaknuti veliku razliku u strukturi kupača. Mikroregija Mali Lošinj demografsko je središte $\mathrm{s}$ gotovo 17 puta većim brojem stanovnika od mikroregije Nerezine, a uz navedeno Mali Lošinj je središte s većim hotelskim kapacitetima, dok su Nerezine orijentirane ponudom na dva manja turistička naselja, kamping turizam, iznajmljivanje apartmana i vikendaške objekte. Među ostalim mikroregijama potrebno je još samo istaknuti dominaciju kamping ponude na prostoru mikroregije Punta Križa.

\footnotetext{
2 Najčešće uniformno tretiranje plaža u literaturi: Valdemoro i Jimenez, (2006), Jurinčič, (2009), Zacarias i dr., (2011), Silva i Ferreira, (2013), Rodella i dr., (2017), Serrano i dr., (2018), Cabezas, (2019), Rodella i dr., (2020) uzrokovano je jednoličnom podlogom.
} 
Tab. 2 Area and share of beaches by selected categories within the microregions of the researched area Tab. 2. Površina i udio plaža po izdvojenim kategorijama unutar mikroregija istraživanoga područja

\begin{tabular}{|l|c|c|c|c|c|c|}
\hline \multirow{2}{*}{$\begin{array}{l}\text { Beach categories } \\
\text { / Kategorije plaža }\end{array}$} & \multicolumn{5}{|c|}{ Tourist microregions / Turističke mikroregije } \\
\cline { 2 - 7 } & Belej-Ustrine & Punta križa & Osor & Nerezine & Mali Lošinj & $\Sigma$ \\
\hline $\begin{array}{l}\text { Beaches within the } \\
\text { settlement } \\
\text { / Plaže unutar naselja } \\
\left(\mathrm{m}^{2}\right)\end{array}$ & $0(0 \%)$ & $2,200(22.3 \%)$ & $750(16.7 \%)$ & $37,900(83.9 \%)$ & $23,800(35 \%)$ & $64,650(49 \%)$ \\
\hline $\begin{array}{l}\text { Beaches outside the } \\
\text { settlement } \\
/ \text { Plaže izvan naselja } \\
\left(\mathrm{m}^{2}\right)\end{array}$ & $4,250(95.5 \%)$ & $6,700(68 \%)$ & $600(13.3 \%)$ & $5,350(11.8 \%)$ & $43,150(63.4 \%)$ & $60,050(45.5 \%)$ \\
\hline $\begin{array}{l}\text { Beaches accessible from } \\
\text { the sea } \\
\text { / Plaže dostupne s mora } \\
\left(\mathrm{m}^{2}\right)\end{array}$ & $200(4.5 \%)$ & $950(9.7 \%)$ & $3,150(70 \%)$ & $1,950(4.3 \%)$ & $1,100(1.6 \%)$ & $7,350(5.5 \%)$ \\
\hline$\Sigma$ & 4.45 & 9.85 & 4.5 & 45.2 & 68.05 & 132.05 \\
\hline
\end{tabular}

Source: independent field mapping Izvor: samostalno terensko kartiranje

Given the new circumstances related to anti-epidemic measures which, according to the recommendation of the Croatian Institute of Public Health (CIPH) from May 2020, relate to maintaining social distance on beaches, it should be noted that it is necessary to enter the correction per bather regarding the estimated PCCs in the category of beaches within settlements. Earlier in this paper, the unit area $\mathrm{Au}$ ) for a normal bathing season for beaches within settlements of $5 \mathrm{~m}^{2}$ per bather (Tab. 3) was stated, while according to the anti-epidemic recommendation of the CIPH, this area should be increased to $6.67 \mathrm{~m}^{23}$ (Tab. 4). If the minimum social distance of 1.5 meters, stated in the same recommendation of the CIPH, is taken into account, then a unit area $(\mathrm{Au})$ of $8.75 \mathrm{~m}^{2}$ per bather is required (Tab. 5) ${ }^{4}$.

3 On May $14^{\text {th }}, 2020$, the Croatian Institute of Public Health (CIPH) issued Recommendations for bathing in sea and inland surface waters during the COVID-19 epidemic, in which point 1 states the recommended simultaneous capacity of 15 people per $100 \mathrm{~m}^{2}$ of beach, or $6.67 \mathrm{~m}^{2}$ per bather.

4 On May $14^{\text {th }}, 2020$, the Croatian Institute of Public Health (CIPH) issued Recommendations for bathing in sea and inland surface waters during the COVID-19 epidemic, in which points 1 and 2 state that the physical distance between people on the beach should be $1.5 \mathrm{~m}$. If the area covered by a person in a supine position covers $1 \times 2 \mathrm{~m}$ and uses a social distance value of $1.5 \mathrm{~m}$ to calculate the physical occupancy of the beach per bather, a unit value of $8.75 \mathrm{~m}^{2}$ per bather is obtained.
S obzirom na novonastale okolnosti vezane uz protuepidemijske mjere koje se po preporuci Hrvatskoga zavoda za javno zdravstvo (HZJZ) iz svibnja 2020. odnose na održavanje socijalne distance na plažama treba uočiti da je na procijenjeni PCC u kategoriji plaže unutar naselja potrebno unijeti korekciju površine po kupaču. Ranije u ovom radu obrazložena je i jedinična površina $(\mathrm{Au})$ za uobičajenu kupališnu sezonu za plaže unutar naselja od $5 \mathrm{~m}^{2}$ po kupaču (tab. 3), dok se po protuepidemijskoj preporuci HZJZ$\mathrm{a}^{3}$ ta površina treba povećati na $6,67 \mathrm{~m}^{2}$ (tab. 4) ili ako se uzme u obzir socijalna distanca od 1,5 metra, navedena u istoj preporuci HZJZ-a, tada se dobije jedinična površina $(\mathrm{Au})$ od $8,75 \mathrm{~m}^{2}$ po kupaču (tab. 5). ${ }^{4}$

\footnotetext{
3 Hrvatsko zavod za javno zdravstvo 14. svibnja 2020. izdao je Preporuke za kupanje u moru i kopnenim površinskim vodama tijekom epidemije COVID-19, unutar kojih se u točki 1. navodi da je dopušten istovremeni boravak 15 osoba na $100 \mathrm{~m}^{2}$ plaže odnosno $6,67 \mathrm{~m}^{2}$ po kupaču.

4 Hrvatski zavod za javno zdravstvo 14. svibnja 2020. izdao je Preporuke za kupanje u moru i kopnenim površinskim vodama tijekom epidemije COVID-19, unutar kojih se u točkama 1. i 2. navodi da je dopuštena fizička udaljenost među osobama na plaži $1,5 \mathrm{~m}$. Ako se u tlocrtu za osobu u ležećem položaju uzme zauzetost površine od 1 x 2 m i koristi vrijednost socijalne distance od $1,5 \mathrm{~m}$ za izračun fizičke zauzetosti plaže po kupaču, dobije se jedinična vrijednost od $8,75 \mathrm{~m}^{2}$ po kupaču.
}

Assessment of acceptable tourism beach carrying capacity in both normal and COVID-19 pandemic conditions - case study of the Town of Mali Lošinj

Procjena prihvatljivog turističkog prihvatnog kapaciteta plaža u normalnim uvjetima i u uvjetima pandemije COVID-19 - studija slučaja Grada Malog Lošinja 
Tab. 3 Estimated physical reception capacity of beaches (in the number of bathers) by selected categories within the microregions of the researched area-normal tourism season SCENARIO 1

Tab. 3. Procijenjeni fizički prihvatni kapacitet plaža (u broju kupača) po izdvojenim kategorijama unutar mikroregija istraživanoga područja - vobičajena turistička sezona SCENARIJ 1

\begin{tabular}{|c|c|c|c|c|c|c|}
\hline \multirow{2}{*}{$\begin{array}{l}\text { Beach categories } \\
\text { / Kategorije plaža }\end{array}$} & \multicolumn{6}{|c|}{ Tourist microregions / Turističke mikroregije } \\
\hline & Belej-Ustrine & Punta križa & Osor & Nerezine & Mali Lošinj & $\Sigma$ \\
\hline $\begin{array}{l}\text { Au - Beaches within the } \\
\text { settlement } \\
/ \mathrm{Au} \text { - Plaže unutar naselja } \\
\left(5 \mathrm{~m}^{2}\right)\end{array}$ & 0 & 440 & 150 & 7,580 & 4,760 & 12,930 \\
\hline $\begin{array}{l}\mathrm{Au} \text { - Beaches outside the } \\
\text { village } \\
\text { / } \mathrm{Au} \text { - Plaže izvan naselja } \\
\left(8 \mathrm{~m}^{2}\right)\end{array}$ & 531 & 838 & 75 & 669 & 5,394 & 7,507 \\
\hline $\begin{array}{l}\mathrm{Au} \text { - Beaches accessible from } \\
\text { the sea } \\
/ \mathrm{Au} \text { - Plaže dostupne s mora } \\
\left(16 \mathrm{~m}^{2}\right)\end{array}$ & 13 & 59 & 167 & 122 & 69 & 430 \\
\hline $\begin{array}{l}\mathrm{PCC}=\mathrm{A} / \mathrm{Au} \times \mathrm{Rf} \\
(\mathrm{Rf}=2)\end{array}$ & 1,088 & 2,674 & 784 & 16,742 & 20,446 & 41,734 \\
\hline
\end{tabular}

Source: independent field mapping

Izvor: samostalno terensko kartiranje

Comparing the calculated PCCs (Tab. 3, 4 and 5) and the tourism intensity in the island's microregions, significant differences can be observed (Tab. 6). It is noticeable that the Osor tourist microregion was markedly lacking in beach space in the 2018 bathing season, according to a comparison of seasonal bathing capacities and the number of overnight stays. The Mali Lošinj microregion was very close to the carrying capacity limit in 2018, while some microregions such as Belej-Ustrine, Punta Križa, and Nerezine had surplus seasonal bathing capacity. Regardless of the shares in the occupancy of beach capacity, the analysis of the absolute values of unused beach carrying capacity by microregion shows that the Nerezine microregion offers the highest future possible seasonal growth in terms of number of bathers. In further interpretation of the aforementioned data in Table 6, it is necessary to take into account that in all microregions the beach load is realised mostly during July and August, while the results of this paper target the total bathing season and the possibility of its extension into June and September. This gives the possibility of relieving the load temporally and spatially to increase sustainability and the economic effect of tourism on the islands.
Usporedbom izračunatih PCC-a (tab. 3, 4 i 5) i turističkoga intenziteta korištenja otoka po mikroregijama mogu se uočiti značajne razlike (tab. 6). Uočljivo je kako je turistička mikroregija Osor u kupališnoj sezoni 2018. godine bila izrazito u deficitu plažnoga prostora prema usporedbi sezonskih kupališnih kapaciteta i broja noćenja. Mikroregija Mali Lošinj 2018. bila je vrlo blizu granice prihvatnoga kapaciteta, dok pojedine mikroregije kao Belej-Ustrine, Punta Križa i Nerezine imaju značajan višak sezonskih kupališnih kapaciteta. Bez obzira na udjele u zauzetosti plažnih kapaciteta analizom apsolutnih vrijednosti neiskorištenoga plažnog prihvatnog kapaciteta po mikroregijama vidljivo je da najveći mogući sezonski rast u broju kupača nudi mikroregija Nerezine. Pri daljnjem tumačenju navedenih podataka u tablici 6 potrebno je voditi računa da se u svim regijama plažna opterećenost ostvaruje najviše tijekom mjeseca srpnja i kolovoza, dok je u rezultatima ovoga rada ciljano naglašena ukupna kupališna sezona i mogućnost njezina produljenja u mjesecima lipnju i rujnu, što daje mogućnost rasterećenja u prostoru te povećanja održivosti i ekonomskoga učinka turizma na otocima. 
Tab. 4 Estimated physical reception capacity of beaches (in the number of bathers) by selected categories within the microregions of the researched area - anti-epidemiological COVID-19, SCENARIO 2

Tab. 4. Procijenjeni fizički prihvatni kapacitet plaža (u broju kupača) po izdvojenim kategorijama unutar mikroregija istraživanoga područja protuepidemijski COVID-19, SCENARIJ 2

\begin{tabular}{|c|c|c|c|c|c|c|}
\hline \multirow{2}{*}{$\begin{array}{l}\text { Beach categories } \\
\text { / Kategorije plaža }\end{array}$} & \multicolumn{6}{|c|}{ Tourist microregions / Turističke mikroregije } \\
\hline & Belej-Ustrine & Punta križa & Osor & Nerezine & Mali Lošinj & $\Sigma$ \\
\hline $\begin{array}{l}\mathrm{Au} \text { - Beaches within the } \\
\text { settlement } \\
\text { / Au - Plaže unutar naselja } \\
\left(6.67 \mathrm{~m}^{2}\right)\end{array}$ & 0 & 330 & 112 & 5,682 & 3,568 & 9,692 \\
\hline $\begin{array}{l}\text { Au - Beaches outside the } \\
\text { village } \\
\text { / } \mathrm{Au} \text { - Plaže izvan naselja } \\
\left(8 \mathrm{~m}^{2}\right)\end{array}$ & 531 & 838 & 75 & 669 & 5,394 & 7,507 \\
\hline $\begin{array}{l}\text { Au - Beaches accessible from } \\
\text { the sea } \\
\text { / Au - Plaže dostupne s mora } \\
\left(16 \mathrm{~m}^{2}\right)\end{array}$ & 13 & 59 & 167 & 122 & 69 & 430 \\
\hline $\begin{array}{l}\mathrm{PCC}=\mathrm{A} / \mathrm{Au} \times \mathrm{Rf} \\
(\mathrm{Rf}=2)\end{array}$ & 1,088 & 2,452 & 707 & 12,933 & 18,044 & 35,224 \\
\hline
\end{tabular}

Source: independent field mapping

Izvor: samostalno terensko kartiranje

Tab. 5 Estimated physical reception capacity of beaches (in the number of bathers) by selected categories within the microregions of the researched area - anti-epidemiological COVID-19, SCENARIO 3

Tab. 5. Procijenjeni fizički prihvatni kapaciteł plaža (u broju kupača) po izdvojenim kategorijama unutar mikroregija istraživanoga područja protuepidemijski COVID-19, SCENARIJ 3

\begin{tabular}{|c|c|c|c|c|c|c|}
\hline \multirow{2}{*}{$\begin{array}{l}\text { Beach categories } \\
\text { / Kategorije plaža }\end{array}$} & \multicolumn{6}{|c|}{ Tourist microregions / Turističke mikroregije } \\
\hline & Belej-Ustrine & Punta križa & Osor & Nerezine & Mali Lošinj & $\Sigma$ \\
\hline $\begin{array}{l}\mathrm{Au} \text { - Beaches within the } \\
\text { settlement } \\
\text { / } \mathrm{Au} \text { - Plaže unutar naselja } \\
\left(6.67 \mathrm{~m}^{2}\right)\end{array}$ & 0 & 330 & 112 & 5,682 & 3,568 & 9,692 \\
\hline $\begin{array}{l}\mathrm{Au} \text { - Beaches outside the } \\
\text { village } \\
\text { / } \mathrm{Au} \text { - Plaže izvan naselja } \\
\left(8 \mathrm{~m}^{2}\right)\end{array}$ & 486 & 766 & 69 & 611 & 4,931 & 6,863 \\
\hline $\begin{array}{l}\mathrm{Au}-\text { Beaches accessible from } \\
\text { the sea } \\
\text { / } \mathrm{Au} \text { - Plaže dostupne s mora } \\
\left(16 \mathrm{~m}^{2}\right)\end{array}$ & 13 & 59 & 167 & 122 & 69 & 430 \\
\hline $\begin{array}{l}\mathrm{PCC}=\mathrm{A} / \mathrm{Au} \times \mathrm{Rf} \\
(\mathrm{Rf}=2)\end{array}$ & 997 & 2,308 & 695 & 12,817 & 17,119 & 33,936 \\
\hline
\end{tabular}

Source: independent field mapping

Izvor: samostalno terensko kartiranje 
Tab. 6 PCC, seasonal capacity and load of beaches according to scenarios by selected categories within the microregions of the researched area in 2018

Tab. 6. PCC, sezonski kapacitet i opterećenost plaža po scenarijima po izdvojenim kategorijama unutar mikroregija istraživanoga područja 2018. godine

\begin{tabular}{|c|c|c|c|c|c|}
\hline \multirow{2}{*}{$\begin{array}{l}\text { Parameters } \\
\text { / Parametri }\end{array}$} & \multicolumn{5}{|c|}{ Tourist microregions / Turističke mikroregije } \\
\hline & Belej-Ustrine & Punta križa & Osor & Nerezine & Mali Lošinj \\
\hline $\begin{array}{l}\text { Number of overnight stays of non-residents } \\
\text { from June to September } \\
\text { / Broj noćenja nerezidenata } \\
\text { od lipnja do rujna }\end{array}$ & 15,018 & 141,064 & 95,688 & 392,756 & $1,328,856$ \\
\hline $\begin{array}{l}\text { Number of overnight stays of residents from } \\
\text { June to September } \\
\text { / Broj noćenja rezidenata } \\
\text { od lipnja do rujna }\end{array}$ & 9,394 & 7,686 & 7,320 & 52,460 & 873,154 \\
\hline PCC - scenario 1 & 1,088 & 2,674 & 784 & 16,742 & 20,446 \\
\hline PCC - scenario 2 & 1,088 & 2,452 & 707 & 12,933 & 18,044 \\
\hline PCC - scenario 3 & 977 & 2,308 & 695 & 12,817 & 17,119 \\
\hline $\begin{array}{l}\text { Seasonal capacity } \\
\text { (number of bathers) season of } 122 \text { days } \\
\text { - scenario } 1 \\
\text { / Sezonski kapacitet } \\
\text { (broj kupača) sezona od } 122 \text { dana } \\
\text { - scenarij } 1\end{array}$ & 132,736 & 326,228 & 95,648 & $2,042,524$ & $2,494,412$ \\
\hline $\begin{array}{l}\text { Seasonal capacity } \\
\text { (number of bathers) season of } 122 \text { days } \\
\text { - scenario } 2 \\
\text { / Sezonski kapacitet } \\
\text { (broj kupača) sezona od } 122 \text { dana } \\
\text { - scenarij } 2\end{array}$ & 132,736 & 299,144 & 86,254 & $1,577,826$ & $2,201,368$ \\
\hline $\begin{array}{l}\text { Seasonal capacity } \\
\text { (number of bathers) season of } 122 \text { days } \\
\text { - scenario } 3 \\
\text { / Sezonski kapacitet } \\
\text { (broj kupača) sezona od } 122 \text { dana } \\
\text { - scenarij } 3\end{array}$ & 119,194 & 281,576 & 84,790 & $1,563,674$ & $2,088,518$ \\
\hline $\begin{array}{l}\text { Beach utilization } \\
\text { (number of bathers) - scenario } 1 \\
\text { / Iskorištenost plaža } \\
\text { (broj kupača) - scenarij } 1\end{array}$ & $18.4 \%$ & $45.6 \%$ & $107.7 \%$ & $21.8 \%$ & $88.3 \%$ \\
\hline $\begin{array}{l}\text { Beach utilization } \\
\text { (number of bathers) - scenario } 2 \\
\text { / Iskorištenost plaža } \\
\text { (broj kupača) - scenarij } 2\end{array}$ & $18.4 \%$ & $49.7 \%$ & $119.4 \%$ & $28.2 \%$ & $100 \%$ \\
\hline $\begin{array}{l}\text { Beach utilization } \\
\text { (number of bathers) - scenario } 3 \\
\text { / Iskorištenost plaža } \\
\text { (broj kupača) - scenarij } 3\end{array}$ & $20.5 \%$ & $52.8 \%$ & $121.5 \%$ & $28.5 \%$ & $105.4 \%$ \\
\hline
\end{tabular}

Source: TZ-GML (2019), DZS (2020), independent field mapping Izvor: TZ-GML (2019); DZS (2020); samostalno terensko kartiranje 
The contingent of people who gravitate to the beaches in the microregion area of the Town of Mali Lošinj also include the inhabitants of the territorial unit itself. Residents on the island are employed during the summer season in tourism and they tend not to visit overcrowded beaches, unlike tourists and weekenders for whom we can say that the main motives for staying on the islands during the summer is sunbathing and swimming (Tab. 6).

In order to calculate the $\mathrm{RCC}$ and $\mathrm{BCI}$ in further analysis, the number of residents using beaches was estimated using the methodology of the National Programme for Management and Management of Sea Beaches - Action Plan (2014). By applying the factor of simultaneity $(\mathrm{Cf}=0.3)$ from the total number of inhabitants (according to the census of settlements) the estimated number of bathers was obtained (Tab. 7). An analysis of the real available area per person per day during the 2018 summer season shows that all microregions according to Serrano et al., (2018) have BCI in the very well category. Comparison with actual areas in the case studies of the nearby research area Lovran which offers $3.26 \mathrm{~m}^{2}$ per bather (Rudan and Krstinić Nižić, 2018) or $3.85 \mathrm{~m}^{2}$ as a comparative study for the Mediterranean (Cabezas, 2019) and further analysis of the values listed as desirable when planning the saturation of beaches of $3 \mathrm{~m}^{2}$ (beach management, 2009) or $4 \mathrm{~m}^{2}$ (Ariza, 2008), it is evident that the beaches of the investigated area offer further qualitative development opportunities during the bathing season (Tab. 7).

ECC beaches can be modelled in relation to $\mathrm{RCC}$, and this is specifically visible in the context of management and branding of beaches with thematic content. The logical sequence of decisions in terms of supporting the improvement of service quality and supply that would follow in the process of raising the categorisation (diversity and quality of services), especially in hotel accommodation, is concessioning individual beaches and increasing the unit area per bather, e.g. with pre-set sunbeds and parasols on the beach. In this process, it is necessary to be very careful because too large areas of such functionally shaped beaches reduce their carrying capacity during periods of peak loads and cause increased loads on nearby beaches, which can cause unwanted experiences among tourists, and problems for locals.
U kontingent osoba koje gravitiraju plažama na području Grada Malog Lošinja moraju se ubrojiti i stanovnici same teritorijalne jedinice. Budući da za razliku od turista i vikendaša za koje možemo reći da im je jedan od osnovnih motiva boravka na otoku tijekom ljeta boravak na plaži i kupanje, rezidenti na otoku su tijekom sezone zaposleni u samom turizmu te im je boravak na plažama (koje su upravo u rezidentima najnapučenijoj turističkoj mikroregiji Mali Lošinj često preopterećene, tab. 6) neatraktivan.

Da bi se u daljnjoj analizi izračunali RCC i BCI, procijenjen je broj rezidenata koji borave na plaži te je u tu svrhu primijenjena metodologija Nacionalnoga program upravljanja i uređenja morskih plaža - akcijski plan (2014). Primjenom faktora istodobnosti (Cf $=0,3$ ) od ukupnoga broja stanovnika (prema popisu stanovništva po naseljima) dobiven je procijenjeni broj kupača rezidenata (tab. 7). Analizom realne raspoložive površine po osobi u danu tijekom sezone 2018. vidljivo je da sve mikroregije prema Serrano i dr., 2018 nude BCI u kategoriji jako dobro. Usporedbom s realnim površinama na susjednom istraživanom području (Lovran) od 3,26 $\mathrm{m}^{2}$ po kupaču ( $\mathrm{Ru}-$ dan i Krstinić Nižić, 2018), 3,85 $\mathrm{m}^{2}$ kao usporednom istraživanju za područje Mediterana (Cabezas, 2019) te vrijednostima koje su poželjne pri planiranju saturacije plaža od $3 \mathrm{~m}^{2}$ (Beach managment, 2009) ili $4 \mathrm{~m}^{2}$ (Ariza, 2008) vidljivo je da plaže istraživanoga područja nude tijekom kupališne sezone daljnju kvalitativnu mogućnost razvoja (tab. 7).

ECC plaža moguće je modelirati u odnosu na $\mathrm{RCC}$, a posebno je to vidljivo u kontekstu menadžmenta i brendiranja plaža $s$ tematskim sadržajima. Logičan slijed odluka u smislu potpore podizanju kvalitete usluge i ponude koja bi slijedila u procesu podizanja kategorizacije (raznovrsnosti i kvalitete usluga) posebice u hotelskom smještaju jest koncesioniranje pojedinih plaža i povećanje jedinične površine po kupaču, primjerice s unaprijed postavljenim ležaljkama i suncobranima na plaži. U ovom procesu treba biti vrlo pažljiv jer prevelike površine ovako funkcionalno oblikovanih plaža smanjuju njihov prihvatni kapacitet u periodima vršnih opterećenja te uzrokuju veće opterećenje na susjedne plažne prostore, što može izazvati neželjene subjektivne doživljaje kod turista, ali i negodovanje lokalnoga stanovništva.
Assessment of acceptable tourism beach carrying capacity in both normal and COVID-19

pandemic conditions - case study of the

Town of Mali Lošinj

Procjena prihvatljivog turističkog prihvatnog kapaciteta plaža u normalnim uvjetima i u uvjetima pandemije COVID-19 - studija slučaja Grada Malog Lošinja 
Tab. 7. RCC and BCl by tourist microregions of the City of Mali Lošinj in 2018

Tab. 7. RCC i BCl po turističkim mikroregijama Grada Malog Lošinja 2018. godine

\begin{tabular}{|l|c|c|c|c|c|}
\hline \multirow{2}{*}{$\begin{array}{l}\text { Parameters } \\
\text { / Parametri }\end{array}$} & \multicolumn{4}{|c|}{ Tourist microregions / Turističke mikroregije } \\
\cline { 2 - 6 } & Belej-Ustrine & Punta križa & Osor & Nerezine & Mali Lošinj \\
\hline $\begin{array}{l}\text { Number of overnight stays of non-residents } \\
\text { from June to September (0.7) } \\
\text { / Broj noćenja nerezidenata } \\
\text { od lipnja do rujna (0.7) }\end{array}$ & 10,513 & 98,745 & 66,982 & 274,929 & 930,199 \\
\hline $\begin{array}{l}\text { Number of overnight stays of residents from } \\
\text { June to September (0.3) } \\
\text { / Broj noćenja rezidenata } \\
\text { od lipnja do rujna (0.3) }\end{array}$ & 2,818 & 2,306 & 2,196 & 15,738 & 261,946 \\
\hline $\begin{array}{l}\text { Total nights during the bathing season } \\
\text { (corrected) }\end{array}$ & 13,331 & 101,051 & 69,178 & 290,667 & $1,192,145$ \\
\hline $\begin{array}{l}\text { / Ukupno noćenja tijekom kupališne sezone } \\
\text { (korigirano) }\end{array}$ & 3,493 & 7,732 & 3,532 & 35,482 & 53,419 \\
\hline $\begin{array}{l}\text { RCC=PCC x Cf } \\
\text { Corrected plaza area } \\
\text { / Korigirana površina plaža }\end{array}$ & 426,146 & 943,304 & 430,904 & $4,328,804$ & $6,517,118$ \\
\hline $\begin{array}{l}\text { Area available during the bathing season } \\
\text { / Površina rasploživa tijekom kupališne sezone }\end{array}$ & 32.0 & 9.3 & 6.2 & 14.9 & 5.5 \\
\hline $\begin{array}{l}\text { Available real area per person per day } \\
\text { (m²) - season 122 days (without Rf) } \\
\text { / Raspoloživa realna površina po osobi u danu } \\
\text { (m²) - sezona 122 dana (bez Rf) }\end{array}$ & & & & \\
\hline
\end{tabular}

Source: DZS (2020), independent field mapping Izvor: DZS (2020); samostalno terensko kartiranje

Applying the $4 \mathrm{~m} \times 4 \mathrm{~m}$ as standard for beach capacity and load management for two sunbeds and one parasol, as used by Wiliams and Micallef (2009) and Rodella et al. (2017), yields a unit area $\mathrm{Au}$ ) with a minimum standard of $8 \mathrm{~m}^{2}$ per bather. In this context, interventions are possible on concessioned beaches where, for example, sunbeds and parasol are placed at pre-planned positions in order to improve the $\mathrm{BCI}$ standard or to meet anti-epidemic COVID-19 measures. If this standard as $\mathrm{Au}$ is hypothetically used for beaches in the microregion of the Town of Mali Lošinj, in the category beaches within the settlement, the carrying capacity on the beaches would be reduced by $37.5 \%$. This would lead to a significant change and thus the capacity of beaches in the microregions of Mali Lošinj and Osor would be so overloaded that demand would spill over to the beaches of neighbouring microregions such as Nerezine.
Primjenom standarda za menadžment kapaciteta i opterećenosti na plažama od $4 \mathrm{~m} \mathrm{x} 4 \mathrm{~m}$ za dvije ležaljke i jedan suncobran koji navode Williams i Micallef, (2009) i Rodella i dr., (2017) dobiva se jedinična površina $(\mathrm{Au}) \mathrm{s}$ minimalnim standardom od $8 \mathrm{~m}^{2}$ po osobi. U ovom kontekstu mogući su zahvati na koncesioniranim plažama gdje se primjerice postavljaju ležaljke i suncobrani prema unaprijed planiranim razmacima i pozicijama kako bi se poboljšao BCI standard ili pak zadovoljila norma protuepidemijskih mjera COVID-19. Kad bi se ovaj standard kao Au hipotetski upotrijebio na cjelokupnom području Grada Malog Lošinja za plaže u kategoriji plaže unutar naselja, smanjio bi se prihvatni kapacitet na plažama za 37,5 \%, što je značajna promjena te bi tada kapaciteti plaža na području mikroregija Mali Lošinj i Osor bili toliko preopterećeni da bi došlo do prelijevanja potražnje za slobodnim plažama na susjedne mikroregije kao što je primjerice mikroregija Nerezine. 
This scenario is feasible in terms of beach capacity, but it would represent a significant change in the mobility of bathers, who would have to travel by car to neighbouring areas. This would probably cause a series of problems in the form of time wasted, lack of parking, and parking fees. In this described example, it can be seen that increasing the quality of the experience on the beaches by increasing Au results in positive shifts for one group of bathers while another (often more numerous) group suffers the negative consequences of these changes. Therefore, in the management of ECC beaches, a careful approach is necessary, taking into account the overall direct and indirect changes in the personal experience of the destination not only on the beach but also for travel time to get to the beach, parking availability, and additional costs.

\section{Conclusion}

By mapping and analysing beaches, as one of the basic tourism spatial resources, it is possible to determine PCC, RCC and ultimately ECC, and thus plan the management of the beaches of a tourist destination. Regarding the example of the case study of beach carrying capacity of the mapped area of the local self-government unit of the Town of Mali Lošinj (Croatia), it can be concluded that the initial hypothesis, i.e. that real carrying capacity of beaches in the researched area (in the usual tourist bathing season) is near the upper load limits, was not confirmed.

The research, however, did confirm the secondary hypothesis: that the real and effective carrying capacity of beaches is not temporally or spatially homogeneous. The bathing season in the researched area lasts from June to September, with an emphasis on the months of July and August, when it can be seen that the beaches are congested in some microregions (Osor and Mali Lošinj). During peak loads, the analysis of PCC of the beaches and the number of tourist stays shows that beaches categorised as beaches within the settlement, especially within the tourist microregions Osor and Mali Lošinj, are heavily burdened under normal circumstances (scenario 1 ), and if anti-epidemic measures were to be applied there would be situations in which beach areas would not be sufficient.
Taj je scenarij glede prihvatnoga kapaciteta plaža ostvariv, ali bi činio značajnu promjenu u mobilnosti kupača koji bi morali putovati osobnim vozilima na susjedna područja za koja bi se vjerojatno pokazao i idući niz problema u vidu potrošnje vremena, manjka parkirališnih mjesta te naplate parkinga. U opisanom je primjeru vidljivo da povećanje kvalitete doživljaja na plažama povećanjem Au rezultira pozitivnim pomacima za jednu skupinu kupača, dok druga (često brojnija) skupina trpi negativne posljedice tih promjena. Stoga je u menadžmentu ECC plaža potreban vrlo pažljiv pristup uzimajući u obzir ukupne izravne i neizravne promjene u doživljaju destinacije ne samo na plaži već i u vremenu potrebnom za dolazak na plažu, troškovima, neudobnosti tijekom vožnje u vrućim automobilima, traženju parkinga itd.

\section{Zaključak}

Kartiranjem i analizom plaža kao jednoga od osnovnih turističkih prostornih resursa može se pristupiti određivanju PCC-a, RCC-a te u konačnici ECC-a te na taj način planski upravljati plažama neke destinacije. Na primjeru studije slučaja analize plažnoga prihvatnog kapaciteta kartiranoga područja teritorijalne jedinice Grad Mali Lošinj može se zaključiti da početna hipoteza kako je realni prihvatni kapacitet plaža na istraživanom području u uvjetima uobičajene turističke kupališne sezone blizu gornjih granica opterećenosti nije potvrđena jer je istraživani prostor kao cjelina ispod granice preopterećenosti s obzirom na prihvatni kapacitet plaža.

Istraživanje je međutim potvrdilo sekundarnu hipotezu da realni i efektivni prihvatni kapacitet plaŽa nije vremenski ni prostorno homogen. Kupališna sezona na istraživanom području traje od lipnja do rujna s naglaskom na mjesece srpanj i kolovoz, kad je vidljivo da u pojedinim mikroregijama (Osor i Mali Lošinj) dolazi do pojave kupališne preopterećenosti plaža. Tijekom vršnih opterećenja prostora analizom PCC-a plaža i broja turističkih noćenja uočljivo je da su plaže kategorizirane kao plaže unutar naselja, a posebice unutar turističke mikroregije Osor te granično unutar mikroregije Mali Lošinj, u uobičajenim okolnostima (scenarij 1) vrlo opterećene, dok se primjenom protuepidemijskih mjera dolazi do moguće situacije da plažne površine nisu dostatne.
Assessment of acceptable tourism beach carrying capacity in both normal and COVID-19

pandemic conditions

- case study of the

Town of Mali Lošinj

Procjena prihvatljivog turističkog prihvatnog kapaciteta plaža u normalnim uvjetima i u uvjetima pandemije COVID-19-studija slučaja Grada Malog Lošinja 
Furthermore, testing the effective carrying capacity of beaches during the application of COVID-19 anti-epidemic measures confirmed the tertiary hypothesis and indicated that the carrying capacity of beaches would be reduced so much that significant changes in tourism in the study area are necessary to offer an acceptable public health standard. In addition, it should be emphasised that the appearance of high saturation of beaches causes a decrease in attractiveness, comfort, and privacy of bathers and potentially jeopardises the tourism quality experience on the beach which further creates a negative impression that tourists take home with them.

The results of this research are primarily intended to assist in sustainable spatial planning and the formulation of development strategies and policies in Croatia and the broader Mediterranean.

Recommendations for action in the context of managing (reducing) the load on beach areas are as follows:

- organising public and/or private transport (by land or sea) of bathers to more distant beaches with additional facilities (thematic beaches, beach branding);

- informing tourists and promoting beaches that are outside of the settlements;

- construction of concessioned parking areas in the hinterland of the beaches (taking into account the ratio of parking spaces and carrying capacity of the beaches);

- equipping the hinterland of the beaches with additional services that would relieve crowding in the contact area adjacent to the sea;

- equipping beaches with pontoon islands for sunbathing or entertainment;

- construction of pools in hotels and private accommodation;

- construction and expansion of water parks facilities;

- construction and expansion of spa wellness facilities;

- concession of beaches with marked places for equipment (sunbeds and parasols) for longer stays on the beach, which is especially recom-
Testiranje efektivnoga prihvatnog kapaciteta plaža tijekom primjene protuepidemijskih mjera $\mathrm{CO}$ VID-19 potvrdilo je tercijarnu hipotezu te upozorilo da se u ovim izmijenjenim okolnostima prihvatni kapacitet plaža toliko smanjuje da su nužne značajne promjene u turizmu istraživanoga područja da bi destinacija dalje nudila prihvatliiv javnozdravstveni standard. Uz navedeno treba naglasiti i da pojava visoke saturacije plaža uzrokuje smanjenje atraktivnosti, ugode $\mathrm{i}$ intimnosti kupača te potencijalno ugrožava kvalitetan turistički doživljaj na plaži što dalje stvara negativan subjektivni dojam koji turisti nose sa sobom po povratku iz destinacije.

Rezultati ovoga istraživanja ponajprije su namijenjeni kao pomoć pri održivom prostornom planiranju i oblikovanju razvojnih strategija i politika na području Hrvatske i Mediterana.

Preporuke za djelovanje u kontekstu upravljanja (smanjivanja) opterećenja plažnoga prostora:

- organiziranje javnoga i/ili privatnoga prijevoza (kopnom ili morem) kupača na udaljenije plaže s dodatnim sadržajima (tematske plaže, brendiranje plaža i sl.)

- informiranje turista i promidžba plaža koje su izvan užega dijela naselja

- izgradnja parkirnih površina pod koncesijom u zaleđu plaža (vodeći računa o odnosu broja parkirnih mjesta i prihvatnoga kapaciteta plaža)

- opremanje zaleđa plaža dodatnim uslugama koje bi rasteretile kontaktni prostor s morem

- opremanje plaža pontonskim otocima za sunčanje ili zabavnim sadržajima

- izgradnja bazenskih kapaciteta u hotelskom i privatnom smještaju

- izgradnja i širenje kapaciteta vodenih zabavnih parkova

- izgradnja i širenje spa wellness kapaciteta

- koncesioniranje plaža s označenim mjestima ili opremom (ležaljke, suncobrani i sl.) za boravak na plaži, što je posebno preporučljivo u situaci- 
mended in situations where anti-epidemic measures are applied; and

- development of a diverse supply of rural destinations in the hinterland offering quality, attractive facilities as an alternative to the beach. jama kod kojih se primjenjuju protuepidemijske mjere

- razvijanje raznovrsnosti ponude ruralnoga zaleđa u destinaciji koja nudi kvalitetne i atraktivne sadržaje kao alternativu boravku na plaži.
Ariza, E., Jiménez, J. A., Sardá, R., 2008: A critical assessment of beach management on the Catalan coast, Ocean \& Coastal Management 51 (2), 141160, https://doi.org/10.1016/j.ocecoaman.2007.02.009.

Ariza, E., Sardá, R., Jiménez, J. A., Mora, J., Ávila, C., 2007: Beyond performance assessment measurements for beach management: application to Spanish Mediterranean beaches, Coastal Management 36 (1), 47-66, https://doi. org/10.1080/08920750701682023.

Cabezas-Rabadán, C., Rodilla, M., Pardo-Pascual, J. E., Herrera-Racionero, P., 2019: Assessing users' expectations and perceptions on different beach types and the need for diverse emanagement frameworks along the Western Mediterranean, Land use policy 81, 219-231, https://doi.org/10.1016/j.landusepol.2018.10.027.

Carić, H., Jakelić, M., 2018: Informed Visitor Management in Protected Areas, Prostor: a scholarly journal of architecture and urban planning 26/1 (55), 146-155, https://doi.org/10.31522/p.26.1(55).11

Chen, C. L., Teng, N., 2016: Management priorities and carrying capacity at a high-use beach from tourists' perspectives: A way towards sustainable beach tourism, Marine Policy 74, 213219, https://doi.org/10.1016/j.marpol.2016.09.030

Corbau, C., Benedetto, G., Congiatu, P. P., Simeoni, U., Carboni, D., 2019: Tourism analysis at Asinara Island (Italy): Carrying capacity and web evaluations in two pocket beaches, Ocean \& coastal management 169, 27-36, https://doi. org/10.1016/j.ocecoaman.2018.12.004.

Da Silva, C. P., 2002: Beach carrying capacity assessment: how important is it? Journal of Coastal Research 36 (1), 190197, https://doi.org/10.2112/15515036-36.sp1.190.

Faivre, S., Mićunović, M., 2017: Reconstructing recent beach morphological changes by repeat photography: example of Zogon Beach on the Island of Hvar (Central Adriatic), Geoadria 22 (2), 165-192, https://doi.org/10.15291/ geoadria.1412

Fernández, J. M., Bértola, G. R., 2015: Tourism carrying capacity of Mar Chiquita beaches, Buenos Aires, Argentina, https://doi.org/10.15359/revmar.6.4.

Jurinčič, I., 2009: Nosilna zmogljivosti Slovenske Istre za turizem, Univerza na Primorskem - Fakulteta za turistične študije Portorož - Turistica, Portorož.

Kovačić, M., Favro, S., Perišić, M., 2010: The Issue of Coastal Zone Management in Croatia -Beach Managing, Academica Turistica 3 (1/2), 53-63.

Kovačić, M., Komać, A., 2011: The issues of beach management in Croatia, with emphasis on Zadar county, Naše more 58 (5-6), 244-255, https://hrcak.srce. $\mathrm{hr} / 75541$.

Magaš, D., Smolčić Jurdana, D., 1999: Metodološki aspekti utvrđivanja prihvatnog potencijala turističkih područ$\mathrm{ja}$, Tourism and hospitality management 5 (1-2), 97-106. https://hrcak.srce. $\mathrm{hr} / 181929$.

Micallef, A., Williams, A. T., Radic, M., \& Ergin, A., 2004: Application of a novel bathing area evaluation technique - a case study of Croatian island beaches, World Leisure Journal 46 (4), 4-21, https://doi.org/10.1080/04419057.200 4.9674370 .

Rajčić, S. T., Faivre, S., Buzjak, N., 2010: The changes in beaches surfaces in the Medići and Mimice area from 1960 till today, Croatian Geographical Bulletin 72 (2), 27-48, https://doi.org/10.21861/ hgg.2010.72.02.02

Rodella, I., Corbau, C., Simeoni, U., Utizi, K., 2017: Assessment of the relationship between geomorphological evolution, carrying capacity and users' perception: Case studies in Emilia-Romagna (Italy), Tourism Management 59,
7-22, https://doi.org/10.1016/j.tourman.2016.07.009.

Rodella, I., Madau, F., Mazzanti, M., Corbau, C., Carboni, D., Simeoni, U., Parente, L., 2020: Carrying capacity as tool for beach economic value assessment (case studies of Italian beaches), Ocean \& Coastal Management 189, 105130, https://doi.org/10.1016/j.ocecoaman.2020.105130.

Rudan, E., Krstinić Nižić, M., 2018: The Role of Beaches in the Tourism Offering: The Case Study of the Municipality of Lovra, Pomorstvo 32 (2), 219-227, https://doi.org/10.31217/p.32.2.7.

Sekulić, B., Fuks, D., 1999: Sanitary Quality of the Adriatic Sea on the Croatian Coastal and Islands Area, Croatian Geographical Bulletin 61 (1), 12-13.

Serrano Giné, D., Jurado Rota, J., Pérez Albert, M. Y., Bonfill Cerveró, C., 2018: The Beach Crowding Index: A Tool for Assessing Social Carrying Capacity of Vulnerable Beaches, The Professional Geographer 70 (3), 412-422, https://doi.org /10.1080/00330124.2017.1416300.

Silva, S. F., Ferreira, J. C., 2013: Beach carrying capacity: The physical and social analysis at Costa de Caparica, Portugal, Journal of Coastal Research, 1039-1044, http://dx.doi.org/10.2112/SI65-176.1.

Valdemoro, H. I., Jiménez, J. A., 2006: The influence of shoreline dynamics on the use and exploitation of Mediterranean tourist beaches, Coastal Management 34 (4), 405-423, https://doi. org/10.1080/08920750600860324.

Williams, A., Micallef, A., 2009: Beach management: principles and practice, Earthscan, London.

Zacarias, D. A., Williams, A. T., Newton, A., 2011: Recreation carrying capacity estimations to support beach management at Praia de Faro, Portugal, Applied Geography 31 (3), 1075-1081. https:// doi.org/10.1016/j.apgeog.2011.01.020.
Assessment of acceptable tourism beach carrying capacity in both normal and COVID-19 pandemic conditions - case study of the Town of Mali Lošinj

Procjena prihvatljivog turističkog prihvatnog kapaciteta plaža u normalnim uvjetima i u uvjetima pandemije COVID-19 - studija slučaja Grada Malog Lošinja

Literature Literatura 
Croatian Bureau of Statistics (DZS), 2020: Census 2011, Population by age and sex, by settlements, https://www.dzs.hr/Hrv/censuses/ census2011/results/htm/H01_01_01/h01_01_01_zup08_2526.html (12.4.2020.)

Croatian Institute of Public Health (CIPH), 2020: Preporuka za kupanje u moru i kopnenim površinskim vodama tijekom epidemije COVID-19 od 14. svibnja 2020., https://www.hzjz.hr/wp-content/uploads/2020/03/Plaze_i_slatkovodna_kupalista_14_05.pdf (15. 5.2020.).

Sources Izvori

Croatian Meteorological and Hydrological Service (DHMZ), 2020: Srednje mjesečne vrijednosti i ekstremi - Mali Lošinj, https:// meteo.hr/klima.php?section=klima_podaci\&param=k1\&Grad=mali_losinj (12.4.2020.)

Fakultet za menadžment u turizmu i ugostiteljstvu, 2015: Regionalni program uređenja i upravljanja morskim plažama na području Primorsko-goranske županije, Opatija.

Ministarstvo turizma Republike Hrvatske, Fakultet za menadžment u turizmu i ugostiteljstvu, 2014: Nacionalni program upravljanja $i$ uređenja morskih plaža - akcijski plan, Opatija.

Ministry of Agriculture, Republic of Croatia, 2020: ARKOD, http://preglednik.arkod.hr (12. 4. 2020.).

Narodne novine: NN, 158/03, 100/04, 141/06, 38/09, 123/11, 56/16: Zakon o pomorskom dobru i morskim lukama.

Primorsko-goranska županija, Županijski zavod za razvoj, prostorno uređenje i zaštitu okoliša, 2013: Prostorni plan Primorsko-goranske županije, 2013. (s ispravkama te izmjenama i dopunama), Službene novine SN 2013-32, SN 2017-07 i SN 2018-41., Rijeka.

State Geodetic Administration, Republic of Croatia, 2020: GEOPORTAL, https://geoportal.dgu.hr/ (12. 4. 2020.).

The Institut for Physical Planning of the Primorje-Gorski Kotar County, Public Institution: GEOPORTAL PGŽ, https://zavod.pgz. hr/geoportal_zupanije (12.4.2020.).

Tourist board of City of Mali Lošinj, 2019: Data from database eVisitor.

UNDP - Centar za regionalne aktivnosti Programa prioritetnih akcija (CRA/PPA), 2010: Održivo upravljanje plažama u Hrvatskoj smjernice i prioritetne akcije, Split.

UNEP - MAP - PAP/RAC, 1997: Guidelines for Carrying Capacity Assessment for Tourism in Mediteranean Coastal Areas, Split.

UNEP - MAP - PAP/RAC, 2003: Guide to Good Practice in Tourism Carrying Capacity Assessment, Split.

Author Autor
Hrvoje Grofelnik $\quad$ hrvoje.grofelnik@fthm.hr PhD, Assistant Professor, University of Rijeka, Faculty of Tourism and Hospitality Management, Primorska 42,

51410 Opatija, Croatia 